\title{
APPEARANCE AND MOMENTARINESS: THE NATURE OF BEING BETWEEN NĀGĀRJUNA, THE SARVĀSTIVĀDINS AND NEO-PARMENIDISM
}

\author{
FEDERICO DIVINO
}

\begin{abstract}
In this article I will try to demonstrate the existence of points in common between the eternalist instances of Parmenidean philosophy and the Buddhist formulations made by some parts of the Abhidhamma, Nāgārjuna, and the Sarvāstivādins. These three philosophies have numerous points in common with Emanuele Severino's formulations from the point of view of what is defined as neo-Parmenidism. The purpose of this article is to demonstrate that the points in common between these systems of thought are due to a basic affinity which, despite having led them to emphasize different themes, present similar reasoning and logical consequences, which allow us to detect very strong points in common especially on issues related to the conception of reality as unique and indivisible in the form of an absolute totality, the eternity of Being, the interdependent nature of entities, and even the illusory perception of worldly reality. Since this text is only an introduction to the problem, I will examine the main issues, also analyzing the main problems to conclude with what I have found to be the actual points in common on which an interdisciplinary dialogue can be built between the problems raised by Severino through Parmenides and Nāgārjuna who from this point of view is more similar to the Sarvasarvädins than has been thought up to now.
\end{abstract}

Keywords: absolutism, being, eternalism, Nāgārjuna, Parmenides, Sarvāstivāda

\section{INTRODUCTION}

For over two centuries after Buddha's death a tradition of studies centered on the deepening and reanalysis of his doctrines has spread and is now known as the Abhidhamma (Sanskrit: Abhidharma) literature. Although it is less studied than the Theravāda Abhidhamma written in Pāli, there is also a tradition derived from a school systematized in Bactria, the Sarvāstivāda, which has produced its own Abhidharma today preserved mostly in Chinese.

The purpose of the Abhidharma is to analyze the psycho-physical phenomenal reality down to its ultimate and not further divisible constitutive elements. The entities

DIVINO, FEDERICO: Ph.D. Candidate in Transcultural Studies, University of Bergamo, Italy. Email: Federico.divino@unibg.it 
The purpose of the Abhidharma is to analyze the psycho-physical phenomenal reality down to its ultimate and not further divisible constitutive elements. The entities analyzed are called dharmas. The doctrine in question is distinguished, in particular, by the conception it gives of dharmas, as they are considered constitutive elements of an indivisible totality. In fact, the term Sarvāstivāda means "everything (sarva) exists (asti)".

Furthermore, the Vaibhāṣika current of the Sarvāstivāda differs from the more orthodox Sautrāntikas, which in fact intend to refer only to the texts (sautra) and reject the Abhidharmic theories, and instead puts forward a particular hypothesis: the threetemporal manifestation of dharmas in the past, present and future.

This theory appears particularly interesting since the aforementioned view of time appears similar to that of some modern exponents of neo-Parmenidism who claim to be able to find the basis for their hypothesis on the persistence of entities over time (or, in other cases, the illusion of the passage of time) in the foundations of Parmenidean thought.

A legitimate question arises spontaneously at this point. Is there a utility beyond comparative philosophy that justifies the comparison between Greek and Buddhist thought? Several parallels have been proposed that suggest a common matrix, or at least a common influence, of the two philosophies and not the simple filiation from one to the other. But there is much more for the question we are dealing with here. It is possible that the two philosophical traditions had common problems to solve. Nathan Tamblyn puts forward a hypothesis that Nāgārjuna's philosophy would be comparable to that of Parmenides for "strong parallels" (Tamblyn 2013). As we shall see, however, the parallels can go much further back than Nāgārjuna's work.

According to Tamblyn, the Zeno paradox reported in Plato's Parmenides can be explained through a Mādhyamika reading: "one thing on its own cannot be different. It can only be different when compared to a second thing. Two things are thus dependent on each other to show their unalikeness" (ibid., 136). The paradox lies in this: although two entities (let's say A and B) are different from each other, they are alike in their being different $(\mathrm{A} \neq \mathrm{B})$. With this, although they are unalike in their relationship from one another, they are alike in their being mutually unalike. They are alike in being unalike and so they are also interdependent $(\mathrm{A} \Leftrightarrow \mathrm{B}){ }^{1}$

Specifically, if the world were to consist of a plurality of independent things, as common sense suggests, then according to Zeno this leads to the paradox that such things would be both like and unlike at the same time and in the same way, thus revealing the absurdity of the original hypothesis. (ibid., 137)

\footnotetext{
${ }^{1}$ We could also say it in another way: since the identity of A depends on its definition in opposition to $\mathrm{B}$, and vice versa that of $\mathrm{B}$ depends on its definition as non-A, there can be no identity of A without $\mathrm{B}$ and vice versa. This entails the paradox that the identity of an entity A depends on the denial of the identity of another entity B on which it (A) depends.
} 
Parmenides' philosophy constantly warns against false conclusions, or false opinions (dóxa) exactly as it happens for the distinction between the dve satye of Madhyamaka. In a revelation of the goddess to Parmenides we also find another important element of Buddhist philosophy, which is the dualistic constitution of conventional reality, to which the Buddha opposes (advaita): "ignorant people distinguish things one from another as opposites, the prime example being light and dark" (ibid., 138). Nāgārjuna and Parmenides also have the same idea of causality, for which it is foolish to say that something arises from nothing (ibid., 140). ${ }^{2}$

Finally, there are further possible parallels between the Parmenidean "what-is" and the Nāgārjunian tattva. For Parmenides the "what-is" is a whole, it is complete and full of itself, and for this reason inviolable or more simply "one" (ibid., 142). Nāgārjuna makes it clear in his work that a totality is the only thing that can be given as paramärtha, and that it is only erroneously perceived (as relative reality) as a set of parts, but paramārtha is not merely the sum of several parts, but rather an indivisible and non-dualistic totality (advaita), that is, without opposing entities (Jones, 2020).

Nāgārjuna and Parmenides are many centuries apart, but Nāgārjuna's philosophy is nothing more than a repurposing of concepts that are already found in the most ancient Buddhism. There is essentially nothing invented or reworked in Nāgārjuna, if not certainly the strength of the rigor and unassailable meticulousness with which he expounds his theses. Parmenides and the Buddha are both temporally placed in the late sixth or early fifth century BC. On the other hand, what is not easy to find in the two philosophies are some subsequent consequences, which those who refer to those thoughts have developed. ${ }^{3}$ We can think that, given the similarity in the premises, it was logical that they would manifest similar developments, but we will see if this is the case.

\section{MANIFESTATION, APPEARANCE AND DISAPPEARANCE: IS THE SARVĀSTIVĀDA ETERNALIST?}

One of the greatest exponents of the neo-Parmenidean current was the philosopher Emanuele Severino. ${ }^{4}$ His thought is very complex, but to an attentive reader it appears

\footnotetext{
${ }^{2}$ Actually, Nāgārjuna structures all his thought on a fourfold denial which is precisely the model of the catușkoti: "a being does not become from [another] being. A being does not become from a non-being. A non-being does not become from a non-being. A non-being does not become from a being. A being does not become from itself, nor from other-than-itself, nor simultaneously from itself and from another. How, then, will it be born?" (na bhāvāj jāyate bhāvo bhāvo 'bhāvān na jāyate | nābhāvāj jāyate 'bhāvo 'bhāvo bhāvān na jāyate || na bhāvāj jāyate bhāvo bhāvo 'bhāvān na jāyate | nābhāvāj jāyate 'bhāvo 'bhāvo bhāvān na jāyate || MK 21.12-13).

${ }^{3}$ Conger for example, believes that Parmenides' philosophy develops in a clear anti-dualist key, which however would presuppose knowledge of Zoroastrian thought, but also of Sāṃkhya (Conger 1952, 122123).

${ }^{4}$ Although this is a common definition attributed to him, it should be noted that some of his students distance themselves from this idea since "Severino's philosophy is quite different from any form of Parmenidism because it is an all-encompassing critique of nihilism (the so called 'night path' of Western thought) taken by the same Parmenides, by post-Parmenidean metaphysics, and, finally, by
} 
to present numerous similarities with some currents of Buddhism. The synthesis of Severino's statements is the one that Professor Priest reports: "there is no change; and so, in particular, if something exists it has always existed and will always exist. As he puts it, 'if Being were to become, it would not be - before its birth and after its corruption"” (Priest 2020, 42).

Some would identify this idea as eternalism. Severino would reject this hypothesis, as he has repeatedly reiterated on several occasions both in his writings and in public that his thought takes adequate distances from both eternalism and nihilism. ${ }^{5}$

Describing the Sarvāstivāda movement at this point becomes complex. Some interpret its name "everything (sarva) exists (asti)" as a form of existentialism, but it must be said that this movement was also opposed by other schools as eternalist. However, the Buddha repeatedly reiterates his position contrary to both nihilism (ucchedavāda) and eternalism (sassatavāda) from which he distances himself (Karunadasa 2018, 14). If this is true it means two possibilities: either the Sarvāstivāda is not eternalist, or the eternalism to which the Buddha referred was different from that of Sarvāstivādins. While nihilism is consistently described as an idea of non-being (vibhava-ditthi), eternalism is described simply as bhava-ditthi. It must first be understood whether the term bhava means something slightly different from simple being. This understanding could change our conception of the idea of eternalism.

Among the problems not yet fully resolved regarding the correct interpretation of the technical terms adopted in the Pâli canon there is undoubtedly the correct interpretation of the verbs atthi and bhavati, which can perform both a copulative function and, depending on the context, indicate the concept of "staying", in the first case, and to "become", in the second case. Since they have always been treated as synonyms, the possibility that these terms should instead be interpreted as very different concepts would also imply the introduction of problems of an ontological order in the Buddhist canon, since these verbs are often alternated in the same sentence, precisely to indicate very different concepts that are opposed, as happens for example in the Niruttipathasutta of the Samyutta Nikāya (22.62). For example, this alternation can be seen in the expression "atthi ti, na tassa saikha bhavissati ti", but this problem is everywhere in the Pāli canon, and its resolution has not yet been found, although is have been several proposals. ${ }^{6}$

contemporary thought. The essence of nihilism is the assumption that time and becoming (considered as annihilation of something) are self-evident, and this initial major error is the basis of all the fundamental logical and ontological errors of both Metaphysics (and metaphysically founded theology) and Science" (Testoni 2019, 123-124).

${ }^{5}$ Those familiar with ancient Buddhist thought will notice the Buddha's similar intentions to distance himself from both eternalisms (sassatavāda) and nihilisms (ucchedavāda), a vision that Nāgārjuna takes up in the title of his own work, devoted to the middle way (madhyamaka) which makes the pair with the median path (majjhimapātipadā) of ancient Buddhism. It should be noted, however, that while in Severino the opposition to nihilism is evident and declared in his works, the rejection of eternalism as a description of his thought has mostly occurred in public interventions, while it is more subtle in his published works.

${ }^{6}$ On March 10, 2014, Professor Peter Harvey held a meeting on this topic for the Oxford Center for Buddhist Studies precisely to report this problem and advance possible solutions to be pursued in the 
In particular, in the passage we have just seen, the use of the verb atthi, whose Indian root is "as", is clearly distinguished from bhavissati, which comes from the root " $b h \bar{u}$ ", from the context which, although traditionally understood as a synonym for "to be", the use, at least in Indian language, has two very different meanings. The idea of atthi (Sanskrit asti) is stative: it indicates something that "is-there", something that is manifest in its existence. ${ }^{7}$

Sections of the kind in which an alternation of these verbs is presented, as well as texts in which to understand the specific meaning of their use, or sections in which they are even explained by the Buddha for what, according to his interpretation, they mean, they are very numerous in Theravāda literature and it is presumed that this use is analogous in the whole Buddhist lexicon, even in that of Sanskrit literature.

The verb atthi (Sanskrit ásti) is in fact referable to the Indo-European root $* h_{l} e s-$ from which the Greek esti and Latin est, while the verb bhavati, as referable to the root $* b^{h} u h_{2^{-}}$, is connected to the forms of the old English bèon (to be, to become) and the Lithuanian büt (to be, to exist).

This choice in translating the verb atthi as a stative form of being while the verb bhavati as a form of "becoming" is based on the analysis of the specific uses of the verb atthi in its occurrences in the Pāli canon. On specific forms and uses of atthi it is possible to detect useful mentions in Cardona $(2014,215)$. On the semantic proximity between bhavati and its derived form hoti as a possible synonym of "becoming" is already evident in the use made of it in the pillars of Aśoka as reported in Cardona (ibid., 182, 190): "hoti 'is, becomes' (bhavati)", and also "Pāli, bhava(ti) 'is, becomes' has this uncontracted form with $b h$ - and a form with initial $h$ - and contracted $-o$ - $<$ avva-" (ibid., 195, 215), and finally "bhüta- (bhavati/hoti)" (ibid., 216, 221). The Buddha adopts this custom, see for example "the eight states of becoming" (bhavam atțamam) mentioned in Ratanasutta.

The hypothesis that we want to bring into play in this context is that the Sarvāstivādin propose a form of eternalism that is not in contradiction with the foundations of Buddhism, as what they consider eternal and permanent in all times is the "what-is" in a static form (asti) which is different from the idea of becoming (bhavati) that pertains instead to the illusory dimension.

On the matter of time, the Sarvāstivāda is described as supporting the following hypothesis: "everything exists everywhere, at all times and in every way" (Willemen, et al. 1998,19). This pertains to the peculiar doctrine already expounded on the theory

linguistic field. The lecture was entitled Reflections on the nature of, and attitudes to, becoming (bhava) in the Päli tradition, and constitutes a fundamental point of reference from which to start.

${ }^{7}$ The term bhavati, on the other hand, is more precisely understood with the meaning of becoming. It is therefore peculiar what the Buddha says in this verse, with reference to the form (but then, similarly to the past verses, he repeats the same formula also for sensation, semantic cognition, mental constructs, and consciousness), which can "appear" (apātubhüta, lit. "manifested", a term that has bhüta in itself as a past participle proper to bhavati), and then, that it will become (bhavissatī). Interesting is also that the sutta points out its conventional nature (paññatti) which, however, is thus harnessed in the conception of bhavati: that is, the convention shapes the form a becoming fact. Different, as the Buddha himself specifies, is something that can be an "is" (atthi) or even less a "was" (ahosi), however, using two terms deriving from very distinct roots. 
of trikäla. It is not clear whether the affirmation of the existence of entities (dharmas) in these three times indicates that the passage of time is only apparent. In other words, it is not clear whether we are talking here about a persistence of the dharmas eternally or rather about their eternal being as not subject to the passage of time.

It all starts with a reflection on causality (hetu). In fact, if the cognitive faculty perceives a given phenomenon that arises before it, it is not possivle to affirm that dharmas last only an instant, as their consequences persist over time: "if the visible, perceived before by the organ of sight and therefore past, were no longer exist, mental consciousness could not arise because of it" (ibid., 20).

Actually, this thesis would be denied if we affirmed that what the cognition continues to perceive is not really the 'true' object, but a sort of cognitive copy that is immediately made at the act of perception (i.e. of the contact between the perceptive organ and the object). The question of the cognitive copy of entities is a very frequent occurrence in Theravāda literature. ${ }^{8}$ The most valid argument of the Sarvāstivādins is that which concerns direct causality: if we see the consequences of a certain phenomenon, it is untenable to affirm that its causes cease to exist only because they are no longer visible in the present.

There are four possible alternatives to explain this view (ibid., 21-26). Given that there are generally three perceivable times as past (atîta), present (pratyutpanna) and future (anāgata), a first hypothesis calls into question the transformations of becoming (bhāvānyathātva) whereby entities maintain their substance (dravya) over time, but not their essence (bhāva). This idea can be translated today into the law of conservation of mass. A vase can be melted and shape-shifted, but the quantity and substance remain the same. Another idea is that the temporal aspect is somehow present in the entities in the form of a mark (lakșananyathātva), therefore an entity that reaches the past from the present is endowed with the characteristic quality of the past, but also does not lose that of the present or the future which it received in the same way when it had those given temporal characteristics. The third hypothesis defends the substance alone (dravya) while, as time changes, it believes that the state of the entity also varies (avasthānyathātva). The last hypothesis calls into question the nomination. As time changes, an entity also varies its nominal quality, and in fact we say of it that it is a past, present or future entity. This idea is called the reciprocity process (anyonyathatva). These three hypotheses are supported respectively by Dharmatrāta, Ghoșaka, Vasumitra and Buddhadeva.

\footnotetext{
${ }^{8}$ According to the Buddhist texts, and particularly in the Abhidhamma literature, nominal expression (kattu-sädhana) has a perceptual doubling as its implication. If we look to the Satipațhāna Sutta we see that in the early Buddhist conception, the cognitive activity is seen as producing a series of perceived doublets on which we must meditate: there is a body-in-the-body (kāye kāya), a mind-in-the-mind (citte citta), a sensation-in-the-sensation (vedanāsu vedāna), an entity-in-the-entity (dhammesu dhamma). We can explain this conception of cognitive doubling if we accept that for the Buddhists the idea of the thing is not the thing itself, but rather a reified double of the thing. But the thing itself is also a conception according to the Abhidhamma. Since this is the basis of meditation practice, it is essential to understand what the Buddha meant when he talks to us about these splits. The nominal expression does exactly this: imposing a distinction by division (abhede bheda-parikappanā) between agent and action, perceiver and perceived, subject and object, and so on.
} 
The *Samyuktābhidharmahrdaya favors the third hypothesis by explaining it as a functional question. Time is a series of states that come progressively into function. In this sense, the future is the function (kāritra) which has yet to be activated. With this, it seems that what is denied is nothing more than the becoming. For example, any acting factor is itself eternal, as a self-identity (svabhāva), but its appearance is momentary (kșanika). We could summarize this vision as a relationship between the time in which a phenomenon that appears is still visible, that is, standing (sthiti), and the moment in which it disappears (anityat $\bar{a})$. The question now is: when an entity disappears, does it cease to exist? The answer of the Sarvastivāda is no: it continues to exist even in the past. However, this implies denying the becoming. Indeed, if a thing became, it would cease to exist as it was in the past and would arise as different from the future in the present. Instead, what is stated is that the entity remains itself (svabhāva) in all times, and what changes is its appearance, so it is our perception that deceives us that something has become other than itself: "all things or elements are real in the past and in the future, as they are real in the present" (ibid., 26). With this, however, we must also point out a contradiction of the Sarvastivāda, which in fact states that for this reason the three times exist separately (ibid.). This appears illogical for a philosophy that is in any case based on interdependence and impermanence (aniccā). Therefore, it is probable that the idea of separateness did not mean their being isolated and independent, but their being clearly distinct.

\section{THE APORIA OF LANGUAGE BETWEEN NĀGĀRJUNA AND SEVERINO}

It is believed that there is an incompatibility between the thought of Nāgārjuna and that of the Sarvasarvādins, since, as Bronkhorst points out (Bronkhorst 2011, 55):

Nāgārjuna had already rejected the possibility that things - meaning dharmas, of course that never arose should pass away. Sarvasarvātmakatvavāda, viewed in this light, would have developed under the influence, this time indirect, of the correspondence principle. This principle rules out the possibility of something non-existent arising. And without arising, there is no passing away.

This idea, however, would contradict what Murti argued when he wrote that Nāgārjuna's philosophy “is a very consistent form of absolutism" (Murti 2008, 147148). So, who is right? The hypothesis I want to put forward is that actually Nāgārjuna was an absolutist, that opposed not so much to the eternalism of the Sarvasarvādins, but rather to their easily misunderstood language. In fact, it appears evident that Nāgārjuna's is a disguised eternalism.

Let's go back to Parmenides and his poem Perí Phýseōs. Parmenides' philosophy founds at the same time a coherent absolutism and an eternalism of this absolute which he calls Being (frag. 2).

hē mèn hópōs éstin te kaì oŷk ésti mè ê̂nai 
"it is and it's impossible that is not" (v. 3)

hē d'hōs ồk éstin te kaì hōs khreṓn esti mè eînai

"it isn't and it is necessary that is not" (v. 5)

The Being is immobile because if it moved it would be subject to becoming, and therefore it would become other than itself, and this would be impossible. From this derives an implicit consideration: language describes a reality that is self-contradictory, since, on the one hand, with the act of vocation, it declares the identity of every being to itself, but, on the other, when it describes becoming it declares contradictorily that the being becomes other than itself: "A has become B", therefore if we say "A is B", we are also saying that " $\mathrm{A}$ is not $\mathrm{A}$ but it is B". 9

For Parmenides, Being is One because there cannot be two Beings: if one is being, the other would not be the first, and would therefore be a non-being. In the same way, if $\mathrm{A}$ is being, and B is different from A, then B is not. Something that is not (the) Being cannot be, by definition. The multiplicity of beings that we see in the world would be nothing more than the consequence of a false opinion (dóxa) which confuses infinite aspects of being as different beings, distinct from each other. For Nāgārjuna this distinction corresponds with the belief in an independent self. Parmenidean Being is indivisible, because otherwise it would require the presence of non-being as a separating element.

For Parmenides, Being is immutable because it cannot be affirmed that it has been or that it will be: if we were to say that being was or will be, in fact, we would fall into contradiction, because in this case we could say that being "is no more" or "not yet". In this, Parmenides agrees with the Sarvasarvādins as he affirms that a being remains itself and does not cease to exist (therefore it does not even become other than itself but, at the most, it changes its perceptible qualities) over time. ${ }^{10}$ Being is therefore ingenerated and immortal, since otherwise it would imply non-being.

${ }^{9}$ A similar problem is presented by Nāgārjuna (Mūlamadhyamakakārikāa, 10.1-2) concerning the relationship between cause and effect: if there is a fire that burns, this happens only because it can consume a fuel, therefore there is no fire without fuel, but fuel is also called "fuel" because it is consumed by a fire. The two entities are therefore interdependent. If this were not admitted then one would implicitly accept that the fire coincides with the fuel, but this would mean that the two are the same. The agent and the object that undergoes the action would be the same thing. If the fire is other than the fuel, [then] it would exist independently from the fuel. Severino, on the other hand, expresses himself in this way: "in the result of becoming ash on the part of the wood, there is not only the ash, but also the having become ash on the part of the wood, an impossible identification of non-identical. We can think of avoiding the contradiction by saying that, in the becoming ash on the part of the wood, the wood becomes nothing. [...] And for this becoming to happen it is also necessary that the ash emerge from nothing: at a certain point, nothing becomes ash, so the result of this becoming from nothing is the being ash on the part of nothing" (Goggi 2019, 51-52). This statement is clearly inspired by Parmenides, for whom Being is "all alike" (pân homô̂on, frag. 8.22).

${ }^{10}$ For the Sarvasarvādins (Willemen, et al. 1998, p. 20) any unit (dravya) is in itself an identity (svabhāva), and in this sense this identity is not nominal or attributed, but is "the identical" in the Severinian sense. For Severino, in fact, every entity that we see is an "identical", that is, it is true and eternal. This does not mean that it has an identity in the sense opposed by Buddhists: Severino's 
In Severino's neo-Parmenidean formulation, the principle of non-contradiction of being becomes an inviolable and implicit fact of everything. Other philosophers who have commented on his work have formulated it like this (Priest 2020, 47):

$\neg \diamond(\mathrm{A} \wedge \neg \mathrm{A})$

The reader will notice how this formulation appears quite analogous to the one that derives from the fourfold negation (catuṣkoți) of Nāgārjuna:

$$
\begin{array}{ll}
\text { 1. } & \neg(\mathrm{A}) ; \\
\text { 2. } & \neg(\neg \mathrm{A}) ; \\
\text { 3. } & \neg(\mathrm{A} \wedge \neg \mathrm{A}) ; \\
\text { 4. } & \neg(\neg \mathrm{A} \wedge \neg \neg \mathrm{A})
\end{array}
$$

Specifically, it is the last logical implication, which includes the negation of any possible alternative, which lends itself to being compared to that of Severino. However, not everyone agrees in using this term and someone proposed this version: $A \vee \neg A$ which seems to me incorrect. ${ }^{11}$ Nevertheless, it is clear if we read any of Nāgārjuna's statements, such as in Mülamadhyamakakārikā (21.12-13):

$$
\begin{aligned}
& \text { na bhāvāj jāyate bhāvo bhāvo 'bhāvānn na jāyate | } \\
& \text { nābhāvāj jāyate 'bhāvo 'bhāvo bhāvān na jāyate || } 12
\end{aligned}
$$

1. (A from A): A being does not become from [another] being,

2. ( $\neg \mathrm{A}$ from $\mathrm{A})$ : nor a non-being [can] become from a being.

3. (A from $\neg \mathrm{A}$ ): A being does not become from a non-being,

4. $(\neg \mathrm{A}$ from $\neg \mathrm{A})$ : nor a non-being [can] become from a non-being.

Which lead to this conclusion:

\footnotetext{
"identical" is not an independent identity, but is a manifestation of Being, and for this reason it is as true as Being in its totality (or rather: it contains in itself the totality of Being). This is also reflected in what Nāgārjuna says: conventional truth (saṃvrti) is not falsehood but only misunderstanding (like the Parmenidean dóxa), and in fact it is not a different o secondary reality distinct from paramārtha as both are satya. The samvrrti is an erroneous and partial view of the totality of paramārtha. To put it in Severinian terms: since relative truth is a conventional misunderstanding of absolute reality, even though it is only a partial vision of the Whole, it must nevertheless be as eternal as the Whole itself. A partial truth is still a truth. This idea for which reality is One but perceived in different ways, giving the illusion of being faced with different realities, is an aspect of Madhyamaka that has been compared with Wilfrid Sellars' philosophy of stereoscopic vision (Garfield 2019, 67-79).

${ }^{11}$ If we "read the negation-symbols as just straight truth-functional negation, both this and the negation of the third alternative turn out to be equivalent to $A \vee \neg A$, and it is obvious that this is not the conclusion Nāgārjuna wants to draw" (Westerhoff 2009, 75). Priest believes that the only way to solve this problem is to formulate the fourth principle as $\neg \mathrm{A} \wedge \neg \neg \mathrm{A}$ but this would cause some logical problems (Priest 2010, 27). Traditional logic cannot explain catușkoți in an absolute sense since Nāgārjuna's will is precisely to reveal the aporia of language.
} 
na svato jāyate bhāvah parato naiva jāyate |

na svataḥ parataś caiva jāyate jāyate kutạ̣ || 13

1. $\neg$ (A from A): A being does not become from itself,

2. $\neg($ A from $\neg \mathrm{A})$ : nor from other-than-itself,

3. $\neg($ A from $A \wedge \neg A)$ : nor simultaneously from itself and from another. In what way, then, will it be born?

At this point it is necessary to consider the Condition of Dialetheism. In fact, Priest argues that it is possible for a given statement to be both true and false at the same time. However, this condition cannot explain the aporia of language since the attribution of nominal identity to entities is based on the assumption of truth. If I affirm that the concept-form Ax corresponds to the name-signifier A $y$ I am also saying that the same association is impossible between the same form $A x$ and a different signifier. If the signifier is "triangle" and the form is $\Delta$ then it is considered correct. If the same signifier is attributed to the form $\square$ then we perceive the statement as false.

When we affirm $\mathrm{A}=\mathrm{A}$ we are operating a real doubling between two "A"s, one image of the other, to allow this affirmation. But the same affirmation is the claim of nominal attribution of language: the phonic execution ['eI] corresponds to the phoneme $/ a /$. In English obviously there are different possible pronunciations of the same phoneme $/ \mathrm{a} /$, such as $/ \mathrm{a} / \equiv[\mathrm{a}] \wedge[\mathrm{a}] \wedge[\mathrm{p}] \wedge[\mathfrak{x}] \wedge[ə] \wedge[\varepsilon] \wedge[\mathrm{o}:] \wedge[0] \wedge[\mathrm{e}] \wedge[\mathrm{C}] \wedge[\wedge]$. But this dialetheism does not deny the two-way principle of language: in fact, if one begins to pronounce the phoneme $/ \mathrm{a} /$ as $[\mathrm{k}]$, he would fall into the contradiction: because $/ \mathrm{a} /=\neg[\mathrm{k}]$. Likewise, the distinction of sonorities in English is pertinent: $/ \mathrm{k} /=$ $[\mathrm{k}] \wedge \neg[\mathrm{g}]$ that is: $/ \mathrm{k} /=[\mathrm{k}] \vee[\mathrm{g}]$. It cannot be both in English. In languages in which the phonetic apparatus does not include sonority as a distinctive feature, then it will be hypothetically possible to say that $/ \mathrm{k} /=[\mathrm{k}] \wedge[\mathrm{g}]$, but in fact these would be languages other than English. Here the system repeats itself. A speaker (A) in whose language sonority is a distinctive trait will perceive the system of a speaker (B) as contradictory in a language where sonority is not a distinctive trait: $\mathrm{A} \neq \mathrm{B}$.

Priest says that "The meaningfulness of a statement of the form ' $a$ is $b$ ' presupposes nothing about either the sense of the reference of ' $a$ ' and ' $b$ '" (Priest 2020, p. 59), not realizing that such a statement simply lacks common sense. It is not a question here of separating absolute logic from the contextuality of discourses, because we must not forget that every system of reasoning, including logic and mathematics, derives from language and functions exactly like human language. Therefore, if it is tolerable to accept a system in which $\mathrm{A}=\mathrm{B}$ it is only because language allows it, but admitting this will does not solve the inherent problem of linguistic aporia, for which nominal identities can function as a device only if one accepts dogmatically their absoluteness, that is their independence, which however contradicts the reality of the system of signs, for which each name takes its meaning from the opposition of all the other names within the system. 


\section{WILL, PREJUDICE AND KNOWLEDGE BETWEEN GREECE AND INDIA}

A famous medieval Latin proverb says nihil volitum quin praecognitum: "nothing is wanted that is not already known". In the light of what we have said so far, we could interpret it as follows: the world populated by a multiplicity of different entities appears to us this way also because a linguistic education acts as a preventive and prejudicial form to our knowledge. Before we can recognize something by its nominal identity it is in fact necessary that a certain meaning is already introjected into our conception of the world. The object "book" appears to us because we have firstly learned to recognize something as "book", but to recognize literally means "to know again" (re-cognōscere), because that notion is already within us, we first learned it through education. Cognition therefore acts as an obstacle between the sight of reality and our understanding of it. In a peculiar metaphor Vasubandhu describes this problem as if our vision was hampered by a cataract: "Since it manifests itself as an unreal object, this world is mere conceptualization, just as an observer with cataract vision of hair on the moon would be" (Viṃśatikā: Vijñaptimātratāsiddhih).$^{12}$ Now, Vasubandhu's original background was precisely the Sarvāstivāda school, and it is not illogical to think that his Yogacāra is a further development of this school, since Yogacāra elements have already been detected in the Abhidharmakośabhāṣya (Kritzer 2005).

This brings us to the last of the comparisons that I propose between the thought of Parmenides and Buddhism. In fact, it is not simple the conception of eternalism that can suggest a comparison. The consequences of this theory in fact lead to two similar conclusions about the nature of human perception.

hōs gàr hekástot'ékhei krâsis meléōn polyplágktōn, tò̀s nóos anthrốpoisi paristatai.

tò gàr aŷtó estin hóper phronéei meléōn phýsis anthrốpoisin kaì pâsin kaì pantí.

tò gàr pléon estì nóêma.

For men's mind comes to them at each time in accordance with the mixture of their much-wandering frame.

For to all men and to each the nature of the frame is the same as what it thinks.

For what preponderates ( $s c$. in the frame) is the thought. (Parmenides, frag. 16) ${ }^{13}$

Vlastos puts forward the fascinating hypothesis that in these verses of Parmenides there are the foundations to support the theory of the identity of perceiver and perceived, which is, the identity of subject and object (Vlastos 1946, p. 67, 68). At the end of the path of enlightenment, the revelation of the identity of subject and object is obviously

${ }^{12}$ Original: vijñaptimātram evaitad asad arthāvabhāsanāt yathā taimirikasyāsat keśa candrādi darśanam.

${ }^{13}$ The translation of the fragment was taken from Vlastos' article on the theory of knowledge in Parmenides (Vlastos 1946, 66). 
also supported by Nāgārjuna (Mūlamādhyamakakārikāa, 23.16-17). ${ }^{14}$ The doctrine of the deceitfulness ${ }^{15}$ of sensory perceptions is therefore probably implicit in the very vision of the unity of Being, as its consequent and necessary admission.

Similarly, there is in Parmenides something very similar to the statement of the impossibility of language to express the paramärtha. For Parmenides it is rather the impossibility of the human to think of Being. This leads to a kind of double nature: that of the wanderer, who sees things as becoming, and that of the "unshaken heart" (frag. 1.29: atremés) which can see the Being. Scholars have questioned whether this view is to be interpreted as a dualism or not, but I believe that the answer has already been given and that it coincides with the Mādhyamika theory of dve satye: there is no duality, only different perceptions of a single truth (Duckworth 2018).

The dualistic vision is the aspect of relative reality, which sees Being as split: on the one hand being as a perceived object, and on the other, Being as a perceiving subject. These two Beings are actually the same Being perceiving itself. This is how mortals "build in their mind to name two forms" (frag. 8.53-54: tồn mían ôy khreón estin). Also, for Parmenides this world constructed by the mind, the world of opinions (dóxa) is a world populated by an (apparent) plurality of nominal entities. At the end of his analysis on the problem of the Name in Parmenides, Woodbury comes to the following conclusions:

Name and world are reciprocally dependent, since a name implies that world of named. Name and world are reciprocally dependent, since a name implies that a world of which it is a name and the world, which must find expression, can find it only if the name is used of itself. (Woodbury 1958, 157)

This peculiar relationship between name and world can already be seen in the most ancient Buddhist texts, such as Lokasutta (AN 4.23), Lokasamudayasutta (SN 35.107), and Pupphasutta (SN 22) in which we read about an entity of a world in the world (loke lokadhammo). ${ }^{16}$ In the other texts mentioned the central theme is the origin and the end of the world (lokassa atthangamo or lokanta, loka-anta). While the origin of the world (lokassa samudayo) is linked to the very foundation of cognitive misunderstanding (from the five aggregates to the attribution of name and form) the end of the world is instead a power that is acquired with the very condition of Buddhahood, and that coincides with the end of the feeding of the conditioned production chain. In numerous texts the figure of the meditator as that of the destroyer of the world (lokantag $\bar{u}$ ). For the Mahāsāmghikas the Buddha, by virtue of his awakened condition, is not confused

\footnotetext{
${ }^{14}$ avidyamāne grāhe ca mithyā vā samyag eva vā | bhaved viparyayah kasya bhavet kasyāviparyayah || na cāpi viparītasya sambhavanti viparyayāh | na cāpy aviparītasya saṃbhavanti viparyayāh ||: "The instrument of perception, the perception itself, the conceiving subject, the perceived object, everything is pacified. Therefore, perception is not detected. But if the perception is not given, whether false or true, to whom can we attribute the misunderstanding or clarity? We cannot attribute misunderstanding to one who is subject to misunderstanding, nor to one who has not been".

${ }^{15}$ Vlastos himself uses the expression "doctrine of the deceitfulness" (Vlastos 1946, 71).

16 "The form, oh beggars, is a norm of the world in the world that the Buddha understands and comprehends" (rüpam, bhikkhave, loke lokadhammo tam tathägato abhisambujjhati abhisameti).
} 
with the worldly nature (laukika) of other human beings. He is supramundane (lokottara), "beyond the world".

antavān yadi lokaḥ syāt paralokạ katham bhavet |

athāpy anantavāl lokah paralokah katham bhavet \|

If the world had an end, how could there be another world?

If the world had no end, how could another world be created?

(Nāgārjuna, Mūlamadhyamakakārikā, 27.21)

Nāgārjuna himself refers to relative reality as "mundane and conventional truth" (lokasamvrtisatyam). ${ }^{17}$ What is in the world belongs to the world, and is inevitably convention, reduction of cognitive space. In fact, as Sasaki reminds us: "the relative represents the things which are considered as existents from the viewpoint of conventional usage (lokanirutti), but not in reality. These things are relative and transitory. They assume a form of limitation also. They reveal themselves as the relative. The relative is a form of manifestation or indication (pañnatti). Both the things, absolute and relative, are thus involved in paññati"' (Sasaki 1986, 82).

Let us now return to the problem of time and momentariness. Admitting therefore, as we have said so far, that the human being is misled by an illusory knowledge, is it possible that this obstructed perception also gives rise to a wrong conception of time and the momentary nature of entities?

sataś ca tāvad bhāvasya nirodho nopapadyate | ekatve na hi bhāvaś ca nābhāvaś copapadyate \|

The annihilation of what exists is impossible. In fact, existence as well as the [affirmation of] non-existence both refer to one and only being, and are therefore illogical.

(Nāgārjuna, Mūlamadhyamakakārikā, 7.30)

The whole theory of the Abhidhamma on the nature of entities (dhammavāda) believes that reality can be analyzed down to its first constituents, namely the dhammas. Already at this level the dhammic reality can be understood as absolute or relative. There is in fact only one unconditioned dhamma, which is nibbana. The conditioned dhammas, on the other hand, are manifold, and are divided into momentary, cognition-based and material phenomena. Here, the Vaibhāșika philosophy disagrees on the momentary nature of the dhammas, which instead believes them to be always permanent. Consistent with this position, in fact, for the Vaibhāșikas "there is no movement in an ultimate sense. [...] Motion is not something that exists in reality (dravyatas), but is a name given to the appearance of momentary elements in adjacent locations

\footnotetext{
${ }^{17}$ The concept of loka maybe has to be recognized as far more important than that of dhamma, and Karunadasa himself states incredibly that all the implications of the fundamental teaching of the Buddha, that is, the dependent arising, are in the way Buddhists understand loka "the world" and sabba "the whole" (Karunadasa 2018, 25). If Karunadasa is correct, this ancient importance of the very idea of the Whole ( $(s a b b a)$ is also the conceptual ground on which concepts like paramattha and tattva arose.
} 
(deśäntarotpatti). If somebody retracted her arm or stretched it forth, in an ultimate sense, it is incorrect to say that her arm moved. What actually happened was that the series of momentary elements that constituted what was called "the arm" arose in adjacent locations in a certain direction. Only the place of the arising of elements had changed, not a single element had moved" (Karunadasa 2020, 68-69).

In the neo-Parmenidean conception of Severino, time is likewise conceived as a sort of coordinate that relates the continuous appearing and disappearing of entities (Totaro 2020, 15). The fact that certain phenomena appear to our cognition does not mean that they begin to exist, nor does their disappearance coincide with their ceasing to exist. Everything is a relationship of entities that are placed inside or outside our field of perceptual appearance. This relationship gives the illusion of becoming but, in reality, these entities that appear and disappear are eternal and immutable, fixed. At this point it is necessary to specify what is the conception of becoming in the NeoParmenidean philosophy to avoid confusion. Severino defines becoming as the nihilistic conception according to which a certain entity is believed to become something else, different than what it is. When we see the term "becoming" used in Neo-Parmenidean philosophy we must therefore understand it as the erroneous appearance that things may change in their substantial identity, a position that is partially shared by the Abhidhamma who believes in the sabhāva of dhammas, but accepts that they cease to exist when their function is exhausted, while the Vaibhāșika Abhidharma accepts instead that the dharmas exist in all temporal aspects (past, present and future), therefore even when they have ceased their function or are no longer visible. These are positions that involve radical considerations of the ancient concept of anicca (impermanence) as well as that of anattā (non-self or non-identity), and which in fact also call into question the position of Nāgārjuna, evidently critical of Abhidharmic constructions but that would need a separate treatment given the complexity of this subject. ${ }^{18}$

\footnotetext{
${ }^{18}$ Although in fact the Abhidharmic terminologies have inspired Nāgārjuna, it must also be said that his position is in clear disagreement with the fundamental assumptions of the intrinsic identity of dharmas. This also calls into question the studies of de Cea (2005) who attempted to demonstrate how Nāgārjuna's philosophy is anti-Abhidharmic and instead centered on the fundamental positions of Early Buddhism, and so when he uses abhidharmic terms, such as paramārtha and svabhāva, he does so with different meanings (in the first case) or to deconstruct its assumptions (in the second case). Beyond de Cea's work, however, this problem should be explored in a second article which I will work on later. For now, I would like to point out these fundamental aspects: The term suñna appears only a few times in the Pāli canon, but every time it occurs it is evident that it is a synonym of anattā or at least of its strengthened form. The Pāli canon refers to identity with the term atta. The act can be applied to both people and objects. If a thing can be named then it is given an identity, and the same goes for psychological identity. It should also be noted that anattā and suñña are perfectly synonymous. The term sabhāva never appears, therefore it is to be thought that the Pāli canon does not distinguish between identity and intrinsic identity. The term sabhāva is an Abhidhammic innovation, perhaps with the aim of specifying that, according to

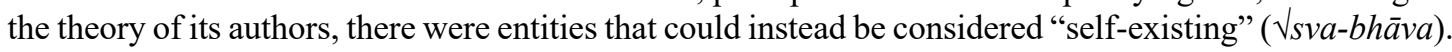
Therefore, when Nāgārjuna uses the term svabhāva it must be understood in an anti-Abhidhammic function. He speaks explicitly on many occasions of the emptiness of atman, but implicitly he also includes svabhāva in this category: "emptiness in the $M M K$ means both emptiness of self and emptiness of svabhāva" (de Cea 2005, 517). Despite this, the emptiness of the svabhāva is one of the central
} 
But what does this appearing and disappearing come from, the Buddhists tell us. Severino just writes that as long as it is impossible for us to conceive of Being as a totality, then we see it partially, and in this partial vision parts of Being appear and disappear, inconceivable as the indivisible infinity that in reality is. But if we look at the Abhidhamma we realize that this partial appearance of beings (which are aspects of Being) is due to the limitation of our cognitive means, that is, by particular causes and conditions.

Things arise, that is, they appear to us, but 1) nothing arises without the appropriate causes and conditions. Furthermore, 2) nothing arises from a single cause, but from a set of several concomitant elements, and 3) no phenomenon arises isolated, single, and solitary, divided from the others (ekassa dhammassa uppatti patisedhitā hoti), precisely because the effects of causes and conditions are always multiple interconnected phenomena. These are the three postulates of the Abhidhamma (Karunadasa 2020, p. 130). It is no coincidence that the Buddha is called "the one who has gone beyond time" (gataddha) which is specifically the samsāric time (samsāraddham atikkanta) or, more specifically, the very concept of duration (addhan).

\section{SUMMARY AND CONCLUSIONS}

In this paper I have tried to demonstrate that common positions between Greek and Buddhist thought can be found since the most ancient forms of the two philosophies. In the various declinations of Buddhist thought there are, mutatis mutandis, numerous points of convergence with statements of Parmenides and with the neo-Parmenidean formulations of Emanuele Severino.

With the term "Being", Severino means "a semantic complex or concreteness whose abstract moments are formal Being and the determination of this formality" (Stella, et al. 2020, 54). The beings (essenti) in Severinian terms are therefore not separated from each other, but interconnected in a network that constitutes a real semantic structure that he defines as "Primal Structure". A more important implication of this interconnectedness is also their implicit inseparability. ${ }^{19}$ This is important to

concepts in Nāgārjuna's work, therefore explicitly in controversy against this "Abhidhammic innovation," which he probably intended as a new and more sophisticated way of understanding identity, which however does not prove it in any way. Since there is no difference between Nagarjuna's sunyata and the Pali anatta (ibid., 518) it is clear at this point that Nāgārjuna notes (and opposes to) a clear contradiction in the Abhidhamma. The Abhidhammic system poses a fundamental distinction: 1) the psyche on the one hand, populated by minimal cognitive data (paññatti) which, however, are shown to the analysis only ephemeral constructs without intrinsic identity; and 2) physical reality on the other hand, which is considered objectively real and populated by minimal structural units (dhamma). Nāgārjuna opposes this dualism by also reducing physical reality to a psycholinguistic construct, or rather: both physical and psychological reality are diminished by the same laws, which can be understood as linguistic laws. With this, however, there is a distortion with respect to the Abhidhammic positions, since all dharmas are seen as impermanent (anity $\bar{a}$ ) conventions or conventionally existent (prajñapti-sat), and therefore ephemeral (śünya).

${ }^{19}$ Already in the Abhidhamma, which probably inspired Nāgārjuna on many points, it is clearly stated that any conditioned dhamma, by its very nature, is totally devoid of power or sway of its own: dhammānam savasavattitābhimāno pațisedhito hoti (Karunadasa 2020, 131). 
understand because in the thesis that we want to propose here, the meaning of multiple beings is the same as the dharmas in Madhyamaka theory.

It is essential to speak of interdependence and not of mere dependence. If A depends on B it is not implied that B depends on something else, as the meaning of "dependence" indicates that only the dependent element needs the other to be substantiated. On the other hand, interdependence implies that the identity of A and B are mutually attributed, but this means that A depends on B as much as B depends on A, like two cards supporting each other in a house of cards.

Severino often speaks of "identity" in an almost absolute sense, which refers not so much to the Buddhist ātman as to the Nāgārjunian tattva, that is, something that has no differences because it includes in itself all the possibilities (therefore also all the differences). However, the way in which Severino considers it presents some problems:

Severino does not accept a ground that is not determined and semanticised, and thus he does not accept an authentic unity, but he interprets unity as unification, which is determined by virtue of the determinateness of the unified determinations. [...] To conclude, we can say that, from a certain point of view, Severino intends to lift duality in the unity and, thus, to achieve the authentic unity; but, from another point of view, he intends to maintain the determinateness and, thus, the relation, which represents a unification, not a unity, because it relies on the duality of the related terms, by virtue of which it maintains its determinateness. (Stella, et al. 2020, 69)

Let's see what we can say about the concept of tattva in Nāgārjuna's thought. If we accept Nāgārjuna's description of reality as having ontological value, then it immediately becomes clear that, for him, Being is not the total of its manifestations, nor the sum of every possible manifestation: "tattva is free of conceptualizations - the distinct objects that our concepts produce are merely our creations" (Jones 2020, 13), and among these "objects", which are mental objects, the idea of Being is also included as it is included the idea of its opposite (non-being). But, we must reiterate it, "tattva is not an entity or collection of entities" (ibidem).

Being as a unit is for Severino the "Whole" that has no otherness as every "other" is in the Being, so that there is no "other" that it is nothing other than Being: "Being is open because the relation that constitutes it is the same relation that opens it to the difference, since the latter is included in Being" (Stella, et al. 2020, 55).

Although Being is per se notum we must deal with the cognitive mediation of language. This is an unclear aspect in Severino's works, who limits himself to affirming that the phenomenological immediacy of being is substantiated in its affirmation: "Being is". And so far I have nothing to object to. But how do we solve the Buddhist problem of the nihilistic perception of reality? How to explain the impermanence that appears to us in all identities?

Severino would say that it is known by itself that Being is, but the Buddha has another problem: who am "I"? Or better: what is "I"?

On the other side, "Nāgārjuna uses "svabhāva" only in connection with bhāvas and dharmas-i.e., alleged entities of one sort or another-not tattva. Tattva is not a type 
of entity that is an alternative to bhāvas and dharmas. Thus, there is no ultimate entities, but there is an "ultimate reality" (tattva)" (Jones 2020, 19).

In conclusion, in this article I have tried to demonstrate how the philosophical questions that Early Buddhism posed are in many respects analogous to those found in ancient Greek philosophy, and we have seen the case of Parmenides. Not only the questions, but also the answers and the ways in which they are sought, are in many respects similar. The philosophical question between the Sarvāstivādin Abhidharma and Nāgārjuna on the problem of the intrinsic identity (svabhāva) of dharmas recalls equally contemporary problems in the neo-Parmenidean movements about eternalism and nihilism. These problems concern the perception of reality, the philosophy of language and cognition, i.e. issues of increasing relevance nowadays, but the way in which I tried to introduce the problems is trans-philosophical and trans-cultural, that is, it uses the tools and philosophical views provided by a certain philosophy to study the analogous problems of another, and vice versa. This gaze that interpenetrates two distinct visions is also the suggestion that this paper wants to give to the philosophical sciences to address contemporary issues by going beyond philosophical comparativism, and 'contaminating' the philosophical visions with each other in the perspective of that Trans-cultural philosophy suggested by authors such as Valera (1972). Transculturality is a tool that allows us to make dialogue on equal terms two philosophical visions, produced in a different historical, social, and linguistic background, but which we firmly believe that they can contribute equally to the philosophical sciences.

For the purpose of this article, I tried to demonstrate that both in Parmenidean and neo-Parmenidean philosophy, as well as in the very basis of ancient Buddhist thought (later reformulated several times above all by Nāgārjunian 'absolutism' and Sarvāstivāda eternalism) we find the affirmation of an ultimate reality, immutable and unspeakable by language, ${ }^{20}$ an infinite Whole not included in the limitations of human

\footnotetext{
${ }^{20}$ Regarding Nāgārjuna's position, clearly hinged on a linguistic-cognitive formulation (Westerhoff 2017), it must be said that it is in many respects referable to that of the Abhidhamma, with the difference that Nāgārjuna applies the same quality of "cognitively constructed" also to dharmas. The quality of samvrti is in fact prajñapti "conceptual", although the conventional reality depends on the absolute one. A conception clearly taken from the Abhidhammic pañnatti. For the Abhidhamma there are two types of designation: the nominal one (näma-pañnatti) and the semantic one (attha-pañnatti). Both cases refer to a clear linguistic conception of conventional reality (sammuti). Indeed, this distinction between nāma and attha also recalls the Saussurian dualism between signifier and signified, which too, as elements of the "two-sided" sign, are conventional designations (pañnatti) that pertain to name and meaning. As conventions, they are unable to describe objective reality, which is believed to be populated by dhammas. Conventions are arbitrary and therefore for the Abhidhamma they are substantially the opposite of the objective dhammic reality, and although a dhamma can be appealed by a name, this does not make it describable by conventional language, which is worldly (lokiya) and therefore linked to the conventional conception of reality. Only the language of the Buddhas is real, but it is also ultramundane (lokuttara). It should be keep in mind, however, that while the Abhidhamma considers pañnattis and dhammas as distinct (Karunadasa 2020), for Nāgārjuna also the dharmas belong to the sphere of prajñapti-sat, thus introducing what later evolved into an even more radical conception in the Yogācāra which considers all the experienceable reality as having a cognitive matrix (cittamātra). Only the condition of Buddhahood remains, even in these cases, the sole capable of transcending language and seeing reality as it is (tattva).
} 
cognition, therefore misunderstood by the discernment of false opinions as a reality populated by multiple entities, which appear and disappear giving us the illusion of becoming..$^{21}$ These entities are cognitively isolated, considered separate, but, in reality, they are impermanent, both because their arising is determined by mutual causes and conditions, and also because they are nothing but multiple aspects of the Whole (tattva), which is indivisible. The two realities, the absolute and the relative, are both truths, but the first is infinite while the second is finite.

Naturally, these issues open the broadest horizons to possible further philosophical insights from a trans-cultural perspective and which can be developed in the space of a future research.

\section{ACKNOWLEDGEMENTS}

This work has not received any public or private funding but derives from studies conducted in parallel with my research work as a Ph.D. Candidate in Transcultural Studies. Finally, I would like to thank the two anonymous reviewers who read the article and sent valuable suggestions that allowed me to refine the contents.

\section{REFERENCES}

Attwood, Jayarava (2018), "Defining Vedanā: Through the Looking Glass", Contemporary Buddhism 19.1: 31-46. <https://doi.org/10.1080/14639947.2018. 1450959>

Beckwith, Christopher (2009), Empires of the Silk Road: A History of Central Eurasia from the Bronze Age to the Present (Princeton: Princeton University Press)

Beckwith, Christopher (2015), Greek Buddha: Pyrrho's Encounter with Early Buddhism in Central Asia (Princeton: Princeton University Press)

Beckwith, Cristopher (2018), "Early Buddhism and Incommensurability", Philosophy East \& West 68.3: 1009-1016. <https://doi.org/10.1353/pew.2018.0084>

Bodhi, Bhikkhu (1993, 1999), A Comprehensive Manual of Abhidhamma: The Abhidhammattha Sangha of Ācariya Anuruddha (Kandy: Buddhist Publication Society)

Bronkhorst, Johannes (2011), Language and Reality. On an Episode in Indian Thought (Leiden: Brill)

Cadorna, George e Jain, Dhanesh (2014), The Indo-Aryan Languages (Oxon: Routledge)

\footnotetext{
${ }^{21}$ As Severino reports in the second Paragraph of his "Returning to Parmenides: 2. The occasions and the Form of the Setting (western Metaphysics is a Physics)" we can find in the Eleatic philosophy the same nominalist idea of ancient Buddhism: "the manifold determinations that appear are all merely "names" (pant'ónoma)" (Severino, 2016).
} 
Cavallera, Hervé (2019) "The "Salvation" in the Truth in Giovanni Gentile and Emanuele Severino", Eternity \& Contradiction. Journal of Fundamental Ontology, 1.1: 57-76. <https://doi.org/10.7346/e\&c-012019-06>

Conger, George (1952), “Did India Influence Early Greek Philosophies?”, Philosophy East and West, 2.2: 102-128. <https://doi.org/10.2307/1397302>

De Cea, Abraham Vélez (2005), "Emptiness in the Pāli Suttas and the Question of Nāgārjuna's Orthodoxy", Philosophy East and West 55.4: 507-528

Duckworth, Douglas (2018), "Sellars and the Stereoscopic Vision of Madhyamaka", in Wilfrid Sellars and Buddhist Philosophy, Routledge (67-79)

Garfield, Jay (2019), Wilfrid Sellars and Buddhist Philosophy: Freedom from Foundations (New York: Taylor \& Francis)

Goggi, Giulio (2019), “"Golden Implication”: The Primary Foundations of the Eternity of Being", Eternity \& Contradiction. Journal of Fundamental Ontology 1.1: 43-56. $<$ https://doi.org/10.7300/e\&c-012019-05.

Jones, Richard (2020), "On what is Real in Nāgārjuna's "Middle Way"”, Comparative Philosophy 11.1: 3-31. <https://doi.org/10.31979/2151-6014(2020).110105>

Karunadasa, Yakupitiyage (2018), Early Buddhist Teachings. The Middle Position on Theory and Practice (Somerville: Wisdom Publications)

Karunadasa, Yakupitiyage (2020), The Buddhist Analysis of Matter (Somerville: Wisdom Publications)

Kritzer, Robert (2005), Vasubandhu and the Yogācārabhümi: Yogācāra elements in the Abhidharmakośabhāsya (Tokyo: The International Institute for Buddhist Studies)

Mishra, Ananda (2018), "Nāgārjuna's Śūnyatā: Beyond Being and Nothingness", Journal of East-West Thought 8.1: 47-53

Murti, Tirupattur Ramaseshayyer Venkatachala (2008), The Central Philosophy of Buddhism. A Study of the Mãdhyamika System (Oxon, London, New York: Routledge)

Nāgārjuna, Mūlamadhyamakakārikā [Fundamentals of the Middle Way]

Parmenides, Perí Phýseōs [On Nature]

Priest, Graham (2020), "Emanuele Severino and the Principle of Non-Contradiction", Eternity \& Contradiction: Journal of Fundamental Ontology 2.2: 42-66. $<$ https://doi.org/10.7346/e\&c-022020-04>

Priest, Graham (2010), "The Logic of Catușkoṭi”, Comparative Philosophy 1.2: 24-54

Ruegg, David Seyfort (2010), The Buddhist Philosophy of the Middle: Essays on Indian and Tibetan Madhyamaka (Boston: Wisdom Publications)

Salomon, Richard (2018), The Buddhist Literature of Ancient Gandhāra: An Introduction with Selected Translations (Somerville: Wisdom Publications)

Sasaki, Genjun (1986), Linguistic Approach to Buddhist Thought (Delhi: Motilal Banarsidass)

Severino, Emanuele (2016), The Essence of Nihilism (London \& New York: Verso)

Stella, Aldo e Ianulardo, Giancarlo (2020), "Reciprocal determination and the unity of distinct determinations in The Primal Structure of Emanuele Severino", Eternity \& 
Contradiction. Journal of Fundamental Ontology 2.3: $52-70<\mathrm{https}$ ://doi.org/ 10.7346/e\&c-032020-05>

Stoneman, Richard (2019), The Greek Experience of India. From Alexander to the Indo-Greeks (Princeton \& Oxford: Princeton University Press)

Tamblyn, Nathan (2013), "Parmenides and Nāgārjuna: A Buddhist Interpretation of Greek Philosophy", Journal of the Oxford Centre for Buddhist Studies 4

Testoni, Ines e Stizzi, Antonio (2020), "Founding a new Theology that affirms the Eternity of Being redressing Emanuele Severino's inquisition Trial", European Journal of Science and Theology 16.6: 37-49

Testoni, Ines (2019), "Eternity between a novel Theology and a New Science from Giordano Bruno to Emanuele Severino", European Journal of Science and Theology 15.5: 117-132

Totaro, Francesco (2020), "The Truth of Being between Unconditional and Conditional", Eternity \& Contradiction. Journal of Fundamental Ontology 2.3: 620. $<$ https://doi.org/10.7346/e\&c-032020-02>

Valera, Eduardo Pérez (1972), "Toward a Transcultural Philosophy", Monumenta Nipponica 27.1: 39-64.

Vlastos, Gregory (1946), "Parmenides' Theory of Knowledge", Transactions and Proceedings of the American Philological Association 77: 66-77. $<\mathrm{https} / /$ doi.org/ $10.2307 / 283445>$

Walser, Joseph (2005), Nāgārjuna in Context: Mahāyāna Buddhism and Early Indian Culture (New York: Columbia University Press)

Westerhoff, Jan (2009), Nāgārjuna's Madhyamaka: A Philosophical introduction (Oxford: Oxford University Press)

Westerhoff, Jan (2017), "Nāgārjuna and the Philosophy of Language", Journal of Indian Philosophy 47:779-793. <https://doi.org/10.1007/s10781-017-9341-3>

Willemen, Charles, Dassein, Bart e Cox, Collett (1998), Sarvāstivāda Buddhist Scholasticism (Leiden: Brill)

Woodbury, Leonard (1958), "Parmenides on Names", Harvard Studies in Classical Philology 63: 145-160. <https://doi.org/10.2307/310851> 